\title{
Effect of Circuit Training and Yogasanas on Cardiovascular Endurance, Inspiratory Capacity and Forced Vital Capacity among Sports Person with Special Reference to Prakriti
}

\author{
Sandeep Singh ${ }^{*}$ and Sangeeta Gehlot \\ Department of Kriya Sharir, Faculty of Ayurveda, Institute of Medical Sciences, Banaras Hindu \\ University, Varanasi - 221005, Uttar Pradesh, India; sandeepsingh160490@gmail.com; \\ sangeetagehlot@gmail.com
}

\begin{abstract}
Background: Circuit training and Yogasana are good for the development of physical and physiological fitness of an individual. These training methods are useful to develop the individual's fitness component like strength, speed, cardiovascular endurance, flexibility and agility as well as physiological components like Forced Vital Capacity (FVC), Inspiratory Capacity (IC) and Expiratory Capacity (EC). Thus, this study was planned to find out the variation of cardiovascular endurance, inspiratory capacity and forced vital capacity among sport persons through circuit training and Yogasana practice in different Prakriti individuals. Materials and Methods: 60 young and healthy male of age group 18-28 years, inter university level sport players were selected and divided into three groups, two experimental group (Yogasana and circuit training group) and one control group. Prakriti of each player was determined by the standard proforma. Harvard step test and PFT was done before and after completion of intervention. Result: After intervention significant changes were found in cardiovascular endurance, forced vital capacity and inspiratory capacity. Pair wise comparison of groups resulted in significant difference between circuit training group v/s control group and Yogasana group v/s control group in FVC and IC, circuit training group v/s Yogasana groups in IC. On Prakriti wise analysis significant changes were observed in all the three parameters of all Prakriti players of circuit training group while, Yogasana group showed significant difference in different parameters. No change was found in control group. Conclusion: Circuit training and Yogasana practices produced almost similar response on all studied parameters.
\end{abstract}

Keywords: Circuit Training, Prakriti

\section{Introduction}

Training is the most important for preparing the athlete for higher level of performance. It is a systematically planned preparation with the help of the exercise which realizes the main factors influencing athlete's progress. The content of training includes all the basic types of preparation of the sportsmen such as physical, technical, tactical and psychological. Circuit training can be designed to develop strength, muscular endurance, speed, agility, neuromuscular coordination, flexibility and cardiovascular 
endurance ${ }^{1}$. Circuit training is an important training in which players perform a series of selected exercise in a sequence or in a circuit at each station and then passes to the next station. The strength of the players may be increased either by increasing the total time or intensity of the work. These stations are allocated throughout the place scratched to the circuit training. Cardiovascular conditioning of the individual depends on the distance between stations ${ }^{2}$. Yoga is the oldest known science originated in ancient India. At present Yogasana are being very popular for the development of physical and mental strength. Many previous studies have reported that Yogic practices improve the physical and mental fitness level as well as the presentation of sports persons in different sports disciplines ${ }^{3,4}$. Some studies have been also taken to evaluate the effect of circuit training on certain physiological parameters ${ }^{5,6}$, effect of breathing exercises on respiratory system and management of diseases related to respiratory system, response of different types of exercises on different physiological parameters have been also proven by previous workers $^{7-10}$. But no study has been carried out to evaluate the comparative effect of circuit training and Yogic practices as per psychosomatic constitution of an individual. Thus, this study was conducted to observe the effect of circuit training and Yogasana as per psychosomatic constitution (Prakriti) of an individual. Prakriti is specific characteristic of an individual which is determined at the time of union of sperm (Shukra) with ovum (Shonita) depends upon the predominance of Dosha (biological entity regulating physiological functions in body) which remains unaltered or throughout the life ${ }^{11}$.

\section{Materials and Method}

For the present study sixty young, healthy, male inter university level sports persons of age between 18 to 28 years were selected through random sampling method. Prakriti of each player was determined at the time of registration by the standard proforma developed by Tripathi et al, 2016 $6^{12}$ Further they were divided in to three groups i.e. two experimental (circuit training and Yogasana) and one control group.

\subsection{Intervention of Circuit Training and Yogasana}

In first experimental group 12 weeks' circuit training was given. In circuit training program total number of stations were ten. Total number of sets were three. Intensity of exercise was increased from low to high according to the training week. In second experimental group 13 different Aasnas were performed by the sports person, while in control group none of these interventions were carried out. Total duration of the intervention was one hour per day for 12 weeks.

\subsection{Collection and Analysis of Data}

Data were collected initially and after the completion of training programs. Harvard step test $\mathrm{t}^{13}$ was used to assess cardiovascular endurance and PFT for forced vital capacity and inspiratory capacity. After collection of data, intergroup and intragroup comparison were done through ANCOVA and paired t- Test by using SPSS 20.

\section{Observations and Results}

Table 1. Group wise pre and post test comparison of subjects showing the effect of circuit training and Yogasana on cardiovascular endurance

\begin{tabular}{|c|c|c|c|}
\hline \multirow{2}{*}{ Groups } & \multicolumn{2}{|c|}{$\begin{array}{c}\text { Cardiovascular Endurance } \\
\text { Mean } \pm \text { SD }\end{array}$} & \multirow{2}{*}{$\begin{array}{l}\text { Within } \\
\text { the group } \\
\text { comparison } \\
\text { Paired t - test }\end{array}$} \\
\hline & Pre & Post & \\
\hline $\begin{array}{c}\text { Circuit } \\
\text { training } \\
\text { Group } \\
(n=20)\end{array}$ & $87.800 \pm 2.149$ & $92.600 \pm 2.542$ & $\begin{array}{l}t=-9.301 \\
p=0.000^{*}\end{array}$ \\
\hline $\begin{array}{c}\text { Yogasana } \\
\text { Group } \\
(n=20)\end{array}$ & $90.200 \pm 3.707$ & $94.200 \pm 3.286$ & $\begin{array}{l}t=-9.903 \\
p=0.000^{*}\end{array}$ \\
\hline $\begin{array}{l}\text { Control } \\
\text { Group } \\
(n=20)\end{array}$ & $88.800 \pm 3.473$ & $89.100 \pm 3.177$ & $\begin{array}{l}t=-0.730 \\
p=0.474\end{array}$ \\
\hline
\end{tabular}

Table 1 shows the mean value of cardiovascular endurance in circuit training, Yogasana and control group from pre to post intervention and on comparing by paired t- test, it was found statistically significant $(p=0.000)$ in circuit training and Yogasana group. 
Table 2. Pair wise group comparison of subjects showing the effect of circuit and Yogasana training on cardiovascular endurance (Index)

\begin{tabular}{|c|c|c|c|c|c|c|c|}
\hline \multicolumn{8}{|c|}{ ANCOVA Cardiovascular Endurance (Index) } \\
\hline \multirow[t]{2}{*}{ Group } & \multirow{2}{*}{$\begin{array}{c}\text { Post Test marginal } \\
\text { Mean } \pm \text { Standard } \\
\text { error }\end{array}$} & \multicolumn{6}{|c|}{$\begin{array}{c}\text { Pre test: covariate, Group: Factor, post test: } \\
\text { dependent variables }\end{array}$} \\
\hline & & SV & SS & Df & MMS & $\mathbf{F}$ & $\mathbf{P}$ \\
\hline Circuit training Group $(\mathrm{N}=\mathbf{2 0})$ & $90.094 \pm 0.309$ & Cardiovascular & & & & & O \\
\hline Yogasana Group $(\mathrm{N}=20)$ & $90.195 \pm 0.311$ & Endurance-pre & 417.222 & 1 & 417.222 & 227.109 & $0.000^{*}$ \\
\hline \multirow[t]{3}{*}{ Control $(\mathrm{N}=20)$} & $89.211 \pm 0.303$ & & & & & & \\
\hline & & Group & 11.684 & 2 & 5.842 & 3.180 & $0.49^{*}$ \\
\hline & $\begin{array}{l}\text { Circuit training v/s } \\
\text { Yogasana } \mathrm{p}-1.000\end{array}$ & & & & & & \\
\hline \multirow[t]{2}{*}{ Pair wise group comparison } & $\begin{array}{l}\text { Circuit training } \\
v / s \text { control } p-0.137\end{array}$ & Error & 102.878 & 56 & 1.837 & & \\
\hline & $\begin{array}{l}\text { Yogasana v/s } \\
\text { control p- } 0.083\end{array}$ & Total & 580.333 & 59 & & & \\
\hline
\end{tabular}

Table 2 shows the comparison of post speed in different groups by applying ANCOVA taking pre value as a covariate, it showed no statistically significant difference between groups $(F=3.180),(p=0.49)$. Further pair wise comparison of groups did not result significant difference between any group.

Table 3. Prakriti wise comparison of subjects showing the effect of circuit and Yogasana training on cardiovascular endurance (Index)

\begin{tabular}{|c|c|c|c|c|}
\hline \multirow{2}{*}{ Groups } & \multirow{2}{*}{ Prakriti } & \multicolumn{2}{|c|}{$\begin{array}{l}\text { Cardiovascular Endurance } \\
\text { Mean } \pm \text { SD }\end{array}$} & \multirow{2}{*}{$\begin{array}{l}\text { Within the group } \\
\text { comparison } \\
\text { Paired t - test }\end{array}$} \\
\hline & & Pre & Post & \\
\hline & Vata $(n=05)$ & $88.000 \pm 1.224$ & $92.000 \pm 2.345$ & $t=3.068 p=0.037^{*}$ \\
\hline \multirow[t]{3}{*}{$\begin{array}{l}\text { Circuit training } \\
\text { Group }(n=20)\end{array}$} & $\operatorname{Pitta}(\mathrm{n}=10)$ & $88.700 \pm 2.668$ & $93.800 \pm 2.485$ & $t=-6.414 p=0.000^{*}$ \\
\hline & $\operatorname{Kapha}(\mathrm{n}=05)$ & $85.800 \pm 1.788$ & $90.800 \pm 1.788$ & $t=9.129 p=0.001^{*}$ \\
\hline & Vata $(n=04)$ & $88.750 \pm 2.872$ & $92.750 \pm 2.629$ & $t=2.248 p=0.110$ \\
\hline \multirow[t]{3}{*}{$\begin{array}{c}\text { Yogasana } \\
\text { Group }(n=20)\end{array}$} & $\operatorname{Pitta}(\mathrm{n}=11)$ & $91.363 \pm 3.042$ & $95.454 \pm 2.464$ & $t=9.867 p=0.000^{*}$ \\
\hline & Kapha $(n=05)$ & $88.800 \pm 5.263$ & $92.600 \pm 4.615$ & $t=7.757 p=0.001^{*}$ \\
\hline & $\operatorname{Vata}(n=04)$ & $89.000 \pm 1.414$ & $87.500 \pm 1.914$ & $t=1.732 p=0.182$ \\
\hline \multirow{2}{*}{$\begin{array}{c}\text { Control } \\
\text { Group }(n=20)\end{array}$} & Pitta $(n=12)$ & $89.250 \pm 4.223$ & $89.583 \pm 3.895$ & $t=0.886 p=0.394$ \\
\hline & Kapha $(n=04)$ & $87.250 \pm 2.217$ & $89.250 \pm 0.500$ & $t=2.000 p=0.139$ \\
\hline
\end{tabular}

Table 3 shows the mean values of cardiovascular endurance in all the three groups as per Prakriti. The t-test was statistically significant in all the three Prakriti in circuit training group. In Yogasana group, mean difference in paired t- test, was found statistically significant in Pitta and Kapha Prakriti while in control group no statistical significance was found. 


\section{Forced Vital capacity}

Table 4. Group wise pre and post test comparison of subjects showing the effect of circuit and Yogasana training on Forced Vital Capacity (in ml)

\begin{tabular}{|c|c|c|c|}
\hline \multirow[t]{2}{*}{ Groups } & \multicolumn{2}{|c|}{$\begin{array}{c}\text { Forced Vital Capacity (ml) } \\
\text { Mean } \pm \text { SD }\end{array}$} & \multirow{2}{*}{$\begin{array}{c}\text { Within the group comparison } \\
\text { Paired t- test }\end{array}$} \\
\hline & Pre & Post & \\
\hline Circuit training Group $(n=20)$ & $3.404 \pm 0.175$ & $3.435 \pm 0.175$ & $t=5.997 p=0.000^{*}$ \\
\hline $\begin{array}{l}\text { Yogasana Group }(n=20) \\
\text { Control Groun }(n=20)\end{array}$ & $\begin{array}{l}3.449 \pm 0.189 \\
3.429+0.216\end{array}$ & $\begin{array}{l}3.477 \pm 0.191 \\
3.434 \pm 0.225\end{array}$ & $\begin{array}{l}t=7.945 p=0.000^{*} \\
t=0.783 p=0.443\end{array}$ \\
\hline
\end{tabular}

Table 4 shows the mean value of forced vital capacity in circuit training, Yogasana and control group from pre to post interventions and on analyzing by paired $t$ - test, it was found statistically significant $(p=0.000)$ in circuit training and Yogasana group.

Table 5. Pair wise group comparison of subjects showing the effect of circuit and Yogasana training on Forced Vital Capacity (in ml)

\begin{tabular}{|c|c|c|c|c|c|c|c|}
\hline \multicolumn{8}{|c|}{$\begin{array}{c}\text { ANCOVA (Forced Vital Capacity })(\mathrm{ml}) \\
\text { Pre test : covariate , Group : Factor, post test: depended variables }\end{array}$} \\
\hline \multirow{2}{*}{ Group } & \multirow{2}{*}{$\begin{array}{l}\text { Post Test marginal } \\
\text { Mean } \pm \text { Standard } \\
\text { error }\end{array}$} & & & & & & \\
\hline & & sv & SS & df & MMS & $\mathbf{F}$ & $\mathbf{P}$ \\
\hline Circuit training Group $(n=20)$ & $3.458 \pm 0.005$ & \multirow{2}{*}{ Vital capacity-pre } & \multirow{2}{*}{2.219} & \multirow{2}{*}{1} & \multirow{2}{*}{2.219} & \multirow{2}{*}{4216.641} & \multirow{2}{*}{$0.000^{*}$} \\
\hline Yogasana Group $(n=20)$ & $3.455 \pm 0.005$ & & & & & & \\
\hline \multirow{2}{*}{ Control $(n=20)$} & $3.432 \pm 0.005$ & & & & & & \\
\hline & $\begin{array}{l}\text { Circuit training v/s } \\
\text { Yogasana } \mathrm{p}-1.00\end{array}$ & Group & 0.008 & 2 & 0.004 & 7.574 & $0.001^{*}$ \\
\hline \multirow[t]{2}{*}{ Pair wise group comparison } & $\begin{array}{l}\text { Circuit training v/s } \\
\text { control } p-0.002\end{array}$ & Error & 0.029 & 56 & 0.001 & & \\
\hline & $\begin{array}{l}\text { Yogasana v/s } \\
\text { control } p-0.009 \\
\end{array}$ & Total & 2.272 & 59 & & & \\
\hline
\end{tabular}

Table 5 shows the comparisons of groups of post forced vital capacity applying ANCOVA taking pre value as a covariate. It showed statistically significant difference between groups $(F=7.574),(p=0.001)$. Furthermore, pair wise comparison of groups resulted in significant $(p=0.002)$ difference between circuit training and control group and was also found to have statistically significant difference $(p=0.009)$ between Yogasana and control group.

Table 6. Prakriti wise comparison of subjects showing the effect of circuit and Yogasana training on Forced Vital Capacity (in ml)

\begin{tabular}{|c|c|c|c|c|}
\hline \multirow[t]{2}{*}{ Groups } & \multirow[t]{2}{*}{ Prakriti } & \multicolumn{2}{|c|}{$\begin{array}{l}\text { Forced Vital Capacity (ml) } \\
\qquad \text { Mean } \pm \text { SD }\end{array}$} & \multirow{2}{*}{$\begin{array}{l}\text { Within the group } \\
\text { comparison } \\
\text { Paired t- test }\end{array}$} \\
\hline & & Pre & Post & \\
\hline \multirow{4}{*}{ Circuit training Group $(n=20)$} & $\operatorname{Vata}(n=05)$ & $3.390 \pm 0.178$ & $3.420 \pm 0.167$ & $t=5.477 p=0.005^{*}$ \\
\hline & $\operatorname{Pitta}(\mathrm{n}=10)$ & $3.362 \pm 0.139$ & $3.380 \pm 0.114$ & $t=4.323 p=0.002^{*}$ \\
\hline & $\operatorname{Kapha}(\mathrm{n}=05)$ & $3.504 \pm 0.230$ & $3.560 \pm 0.208$ & $t=4.635 p=0.010^{*}$ \\
\hline & Vata $(n=04)$ & $3.465 \pm 0.110$ & $3.495 \pm 0.100$ & $\mathrm{t}=4.243 \mathrm{p}=0.024^{*}$ \\
\hline \multirow[t]{3}{*}{ Yogasana Group $(n=20)$} & $\operatorname{Pitta}(\mathrm{n}=11)$ & $3.429 \pm 0.221$ & $3.455 \pm 0.223$ & $t=9.459 p=0.000^{*}$ \\
\hline & Kapha $(n=05)$ & $3.480 \pm 0.191$ & $3.510 \pm 0.198$ & $t=2.372 p=0.077$ \\
\hline & $\operatorname{Vata}(n=04)$ & $3.462 \pm 0.119$ & $3.467 \pm 0.124$ & $t=1.000 p=0.391$ \\
\hline \multirow[t]{2}{*}{ Control Group $(n=20)$} & Pitta $(n=12)$ & $3.445 \pm 0.257$ & $3.451 \pm 0.270$ & $t=0.549 p=0.594$ \\
\hline & $\operatorname{Kapha}(\mathrm{n}=04)$ & $3.345 \pm 0.150$ & $3.347 \pm 0.156$ & $t=0.522 p=0.638$ \\
\hline
\end{tabular}

Table 6 shows the mean values of forced vital capacity in all the three groups as per Prakriti. The paired t- test showed a statistically significance in all the three Prakriti in circuit training group. In Yogasana group, mean difference on testing by paired t- test, was found statistically significant in Vata and Pitta Prakriti while in control group no statistical significance was found. 


\section{Inspiratory Capacity}

Table 7. Group wise pre and post test comparison of subjects showing the effect of circuit and Yogasana training on inspiratory capacity (in ml)

\begin{tabular}{lccc}
\hline \multicolumn{1}{c}{ Groups } & \multicolumn{2}{c}{$\begin{array}{c}\text { Inspiratory capacity }(\mathbf{m l}) \\
\text { Mean } \pm \text { SD }\end{array}$} & $\begin{array}{c}\text { Within the group comparison } \\
\text { Paired t- test }\end{array}$ \\
\cline { 2 - 3 } & Pre & Post & $\mathrm{t}=8.441 \mathrm{p}=0.000^{*}$ \\
Circuit training Group $(\mathbf{n}=\mathbf{2 0})$ & $2.674 \pm 0.199$ & $2.704 \pm 0.204$ & $\mathrm{t}=7.933 \mathrm{p}=0.000^{*}$ \\
Yogasana Group $(\mathbf{n = 2 0 )}$ & $2.603 \pm 0.975$ & $2.622 \pm 0.101$ & $\mathrm{t}=0.175 \mathrm{p}=0.863$ \\
Control Group $(\mathbf{n = 2 0 )}$ & $2.643 \pm 0.282$ & $2.650 \pm 0.286$ & \\
\hline
\end{tabular}

Table 7 shows the mean value of inspiratory capacity in circuit training, Yogasana and control group from pre to post interventions and on analyzing by paired $t$ - test, it was found statistically significant $(p=0.000)$ in circuit training and Yogasana group only.

Table 8. Pair wise group comparison of subjects showing the effect of circuit and Yogasana training on inspiratory capacity (in ml)

\begin{tabular}{|c|c|c|c|c|c|c|c|}
\hline \multicolumn{8}{|c|}{$\begin{array}{c}\text { ANCOVA (Inspiratory capacity })(\mathrm{ml}) \\
\text { Pre test : covariate , Group : Factor, post test: depended variables }\end{array}$} \\
\hline \multirow{2}{*}{ Group } & \multirow{2}{*}{$\begin{array}{l}\text { Post Test marginal } \\
\text { Mean } \pm \text { Standard } \\
\text { error }\end{array}$} & & & & & & \\
\hline & & sv & SS & df & MMS & $\mathbf{F}$ & $\mathbf{P}$ \\
\hline Circuit training Group $(n=20)$ & $2.670 \pm 0.003$ & Inspiratory & & & & & \\
\hline Yogasana Group $(n=20)$ & $2.660 \pm 0.003$ & capacity-pre & 2.545 & 1 & 2.543 & $1 / 158.185$ & $0.000^{n}$ \\
\hline \multirow[t]{2}{*}{ Control $(n=20)$} & $2.647 \pm 0.003$ & & & & & & \\
\hline & $\begin{array}{l}\text { Circuit training v/s Yogasana } \\
\qquad \mathrm{p}-0.049\end{array}$ & Group & 0.005 & 2 & 0.003 & 16.989 & $0.000^{*}$ \\
\hline \multirow[t]{2}{*}{ Pair wise group comparison } & $\begin{array}{l}\text { Circuit training v/s control } \\
\qquad \mathrm{p}-0.000\end{array}$ & Error & 0.008 & 56 & 0.000 & & \\
\hline & $\begin{array}{l}\text { Yogasana v/s } \\
\text { control p- } 0.005\end{array}$ & Total & 2.623 & 59 & & & \\
\hline
\end{tabular}

Table 8 shows the comparisons of groups on post inspiratory capacity. On applying ANCOVA taking pre value as a covariate, showed statistically significant difference between groups $(F=16.989)$, $(p=0.000)$. Furthermore, pair wise comparison of groups resulted in significant $(p=0.000)$ difference between circuit training and control group. It was found statistically significant $(p=0.005)$ between Yogasana and control group and also found statistically significant $(p=0.049)$ between circuit training and Yogasana group.

Table 9. Prakriti wise comparison of subjects showing the effect of circuit and Yogasana training on inspiratory capacity (in ml)

\begin{tabular}{|c|c|c|c|c|}
\hline \multirow{2}{*}{ Groups } & \multirow{2}{*}{ Prakriti } & \multicolumn{2}{|c|}{$\begin{array}{c}\text { Inspiratory Capacity (ml) } \\
\text { Mean } \pm \text { SD }\end{array}$} & \multirow{2}{*}{$\begin{array}{c}\text { Within the group } \\
\text { comparison } \\
\text { Paired t- test }\end{array}$} \\
\hline & & Pre & Post & \\
\hline & Vata $(n=05)$ & $2.572 \pm 0.097$ & $2.600 \pm 0.101$ & $t=5.715 p=0.005^{*}$ \\
\hline \multirow[t]{3}{*}{ Circuit training Group $(\mathrm{N}=20)$} & $\operatorname{Pitta}(\mathrm{n}=10)$ & $2.727 \pm 0.193$ & $2.759 \pm 0.205$ & $t=4.824 p=0.001^{*}$ \\
\hline & $\operatorname{Kapha}(\mathrm{n}=05)$ & $2.672 \pm 0.272$ & $2.700 \pm 0.270$ & $t=7.483 p=0.002^{*}$ \\
\hline & Vata $(n=04)$ & $2.595 \pm 0.051$ & $2.620 \pm 0.049$ & $t=8.660 p=0.003^{*}$ \\
\hline \multirow[t]{3}{*}{ Yogasana Group ( $\mathbf{N}=20)$} & $\operatorname{Pitta}(\mathrm{n}=11)$ & $2.613 \pm 0.104$ & $2.631 \pm 0.111$ & $t=4.541 p=0.001^{*}$ \\
\hline & Kapha $(n=05)$ & $2.588 \pm 0.123$ & $2.604 \pm 0.124$ & $t=6.532 p=0.003^{*}$ \\
\hline & $\operatorname{Vata}(\mathrm{n}=04)$ & $2.517 \pm 0.277$ & $2.520 \pm 0.286$ & $t=0.397 p=-0.718$ \\
\hline \multirow[t]{2}{*}{ Control Group ( $N=20$ ) } & Pitta $(n=12)$ & $2.697 \pm 0.326$ & $2.707 \pm 0.329$ & $t=0.200 p=0.845$ \\
\hline & Kapha $(n=04)$ & $2.607 \pm 0.059$ & $2.610 \pm 0.052$ & $t=0.522 p=0.638$ \\
\hline
\end{tabular}

Table 9 shows the mean values of forced vital capacity in all the three groups as per Prakriti. Paired t- test showed statistical significance in all the three Prakriti of circuit training group as well as in Yogasana group while, control group showed no statistical significance. 


\section{Discussion}

\subsection{Cardiovascular Endurance}

Development of cardiovascular endurance is a long term process. In current study, training schedule was only for three months, which might be the cause of non-significant change on intergroup comparison. As per Prakriti maximum cardiac index was observed in Pitta Prakriti then Kapha Prakriti of both the groups i.e. Yogasana and circuit training group. Minimum cardiac efficiency was found among Vata Prakriti sports person in both the groups. As per descriptions available in Vata Prakriti, Pitta and Kapha Prakriti individuals possess minimum moderate and maximum strength which might be one of the reasons for this finding ${ }^{14}$. Tripathi et al. (2009) have conducted a study on certain cardiovascular responses in clinically healthy individuals with special reference to their Prakriti. This study reported better cardiac efficiency index in Vata-Pitta and Pitta-Kapha Prakriti individuals. In this study Dwandaja Prakriti was considered and Pitta is common in both groups ${ }^{15}$.

\subsection{Forced Vital Capacity}

Forced vital capacity was significantly changed in all Prakriti individuals except Kapha Prakriti of Yogasana group. On Prakriti wise comparison, it was found maximum in Pitta Prakriti and minimum in Kapha Prakriti individuals. Kaithal et al. have reported increased forced vital capacity in all the Prakriti individuals and was maximum in Kapha Prakriti individuals but it was not found significant ${ }^{16}$. However in current study significant change was found in circuit training (p-0.000) and Yogasana (p-0.000) as per Prakriti. FVC was maximum in Kapha Prakriti individuals, might be due to their well-formed chest as compared to others, as described in Ayurveda. Moreover, their muscle power is also good which might have increased better functioning of respiratory muscles ${ }^{14}$.

\subsection{Inspiratory Capacity}

Inspiratory capacity is a maximum amount of air that a person can breathe in with maximum effort, starting from the normal end-expiratory point, it is about $3000 \mathrm{ml}$ ${ }^{17}$. In the case of inspiratory capacity, a positive change was observed in both Yogasanas and circuit training group when compared to control group. This positive result in the inspiratory capacity of the subjects may be due to the fact the subjects regularly practiced various kinds of aerobics in the circuit such as skipping, squad jump etc., Performing Yogasana for such a long time may have also improved the inspiratory capacity. In case of inspiratory capacity significant changes were found in all three Prakriti individuals, comparatively Pitta Prakriti people had more significant change. This might be due to more metabolic demand of Pitta Prakriti individuals ${ }^{14}$ as they already possess more metabolic activities than other Prakriti individuals.

\section{Conclusion}

Twelve-week intervention of circuit training and Yoga sana has resulted in significant changes in cardiovascular endurance, forced vital capacity and inspiratory capacity. On inter group comparison (circuit training and Yogasana) significant changes were observed for forced vital capacity and inspiratory capacity. No significant change was observed for cardiovascular endurance. On comparison as per Prakriti, forced vital capacity and inspiratory capacity varied in all the Prakriti individuals of circuit training group while in Yogasana group, inspiratory capacity changes in all the Prakriti players, cardiovascular endurance varied in Pitta and Kapha Prakriti while forced vital capacity was changed in Vata and Pitta Prakriti. However, a study with large sample for long duration is required to find more responses on these parameters.

\section{Conflict of Interest}

There is no conflict of interest to declare.

\section{Acknowledgement}

To all the volunteers of this study for their active participation.

\section{References}

1. Singh H. Science of sports training. New Delhi: D.V.S. Publication; 1991.

2. Singh A, Bains J, Gill JS. Essentials of Physical Education. New Delhi: Kalyani Publishers; 2003. 
3. Iyanger BKS. The Illustrated Light on yoga, Yoga Dipika. 10th edition. India: Harper Collins Publication; 2005.

4. BalajiPA, VarneSR,AliSS.Physiologicaleffectsofyogicpractices and transcendental meditation in health and disease. North American Journal of Medicine Sciences. 2012; 4(10):442-8. https://doi.org/10.4103/1947-2714.101980. PMid: 23112963. PMCid:PMC3482773

5. Daniel MV, Jesus V. Effects of a circuit training program on muscular and cardiovascular enduranceand their maintenance inschoolchildren. JournalofHuman Kinetics. 2013;37:153-60. https://doi.org/10.2478/hukin-2013-0036. PMid: 24146716. PMCid:PMC3796833

6. Xavier MR. Comparative effect of plyometric, circuit training and circuit breaker programs on selected motor components of school level basketball players. Indian Stream Research Journal. 2012; 10(2):1-4.

7. Tiwari S, Gehlot S, Tiwari SK. How walking is supportive in prevention of hypertension as per Prakriti. The Indian Journal of Research Anvikshiki. 2012; 6(1):7-14

8. Tiwari S, Gehlot S. Overview of Vyayam (Physical exercise). Journal of Physiological and Scientific Opinion. 2014; 2(6):359-62. https://doi.org/10.7897/2321-6328.02682

9. Tiwari S, Gehlot S, Tiwari SK, Singh G. Effect of walking (Aerobic isotonic exercise) on physiological variants with special reference to Prameha (Diabetes mellitus) as per Prakriti. Ayu. 2012; 33(1):44-9. https://doi.org/10.4103/09748520.100308. PMid: 23049183. PMCid:PMC3456862

10. Tiwari S, Gehlot S, Tiwari SK, Singh G. Effect of isotonic exercise on various physiological parameters in hypertension. Journal of Stress Physiology and Biochemistry. 2012; 7(3).
11. Shrikanth KRM. Sushruta Samhita of Sushruta. Editor. Reprint ed. Sharirasthana: Chapter 4: Garbhvyakaranashariraadhyaya, verse 62. Varanasi: Chaukhambha Orientalia; 2008.

12. Tripathi PK, Gehlot S. A physio-anatomical study of prakriti. [Internet]. [cited 2017 Nov 8]. Available from: http://www. lulu.com/ca/fr/shop/piyush-kumar-tripathi-and-sangeetagehlot/a-physio-anatomical-study-of-prakriti/paperback/ product-23213334.html.

13. Kansal D. Test and measurement in sports and physical education. New Delhi: D.V.S Publications; 1996.

14. SharmaRK,DasB.Editors. CharakSamhita of Agnivesh.Reprint edition. Vimanasthana: Chapter 8: Rogabhisagjitiyaadhyaya, verse 96-98. Varanasi: Chowkhambha Sanskrit Series Office; 2015.

15. Tripathi P, Patwardhan K, Singh G. The basic cardiovascular responses to postural changes, exercise and cold pressor test: Do they vary in accordance with the dual constitutional types of Ayurveda? ECAM; 2011. https://doi.org/10.1155/2011/251850. PMid: 20953421. PMCid:PMC2952295

16. Kaithal D, Tripathi NS, Singh V. Effect of aerobic and anaerobic training on certain Physiological, body composition parameters and Performance among soccer players with special reference to Prakriti (psycho-somatic constitution). Ph.D. thesis in department of Kriya Sharir, Faculty of Ayurveda, IMS, BHU; 2019

17. Ghai CL. Textbook of practical physiology ( $8^{\text {th }}$ edition). India, New Delhi: Jaypee brothers medical publishers); 2013. 